\title{
Research on the Brand Marketing Strategy of Chinese Clothing Enterprises
}

\author{
Xiuying Dai \\ Changchun University of Science and Technology \\ Changchun 130022, China \\ E-mail: d7906@163.com \\ Juan Zhang \\ Changchun University of Science and Technology \\ Changchun 130022, China \\ E-mail: zhangjuan5791@163.com
}

\begin{abstract}
China is the world's largest clothing manufacturing country, but China has not the international top clothing brands, How to improve the competitiveness of our clothing brands in the market. This paper analyzed the problems in the development of Chinese clothing brand and put forward the brand marketing strategy of clothing enterprises in China.
\end{abstract}

Keywords: Clothing brand, Brand marketing, Strategy

Textile and garment industry is one of China's traditional pillar industries and played a very important role in the development of the national economy. With the reform and opening up, the share of textile and apparel exports increased year by year. The current account of China Garments is one-fifth of the world clothing market share and export all over the world in 220 countries and regions. According to statistics, every three garments in the world, there is one produced in China, China has become the world's largest garment producer and exporter. After decades of development, China's clothing brand has reached many thousands, gathered in the era of world famous brand clothing, but not a clothing brand to a worldwide reputation. Thus, if China's garment industry wants to be succeeding in the international well-known clothing brands and occupy seats, brands marketing reform is need to improve China's apparel brand in the world market competitiveness.

\section{Brand development problems of China's garment enterprises}

China's clothing production ranks is first in the world, but China's apparel brand awareness is not high, the Chinese garment enterprises to some extent remain in the step of the high-volume, low price, lack of market influence, how to improve the competitiveness of our apparel brands in the international market, which should be seriously examine brand problem in the development of China's garment.

\subsection{Brand awareness is not strong; ignore the establishment of independent brands}

Brand awareness is not strong the major reason that made apparel brand development behind in the international market. At present, medium and small garment enterprises, especially in the T-shirts manufacturers still use more OEM marketing. OEM marketing allows businesses in a very short period of time to achieve maximum benefits. But long-term perspective, not own brand of products is difficult to establish a fully independent distribution network, easily controlled by others. Companies are difficult to place in the market competition.

\subsection{Brand positioning is not accurate enough}

Philip Kotler pointed out that the positioning is to identify differences between competitors and to effectively explain to the target market how the difference between it and its competitors. When brand founded in the early stages, some garment enterprises do not do preliminary market research, not able to make a exactly brand market segmentation, and brand positioning is not starting from a consumer's mind but with monotonous on the product itself, which causing the brand is not with the inner needs that resonate with consumers. Brand positioning is not accurate enough and brand personality is not exactly which lead to feature not prominent in the market 
competition, differentiation was not obvious, so marketing strategy plan does not match advertising content with the product and the consumers didn't agree. In the end the enterprises use prices to win consumers.

\subsection{A single model of brand marketing in garment enterprises}

The marketing model in most of the clothing enterprises in China still relies on the choice of the enterprise which consists of a number of subsidiaries or branches. The one-stop marketing style of use production supply to promote sales, which only transferred the product inventory amount to the distribution company and there was no real product sales. When the accumulation exceed, the discounts and other promotions will be used for product sales. This only caused the price of consumer products concern, has not reached the purpose of consumers concerned about the brand, over time, consumer spending fun loss, loss of consumer brand loyalty and result in increased business costs, the vicious circle of falling profits.

\subsection{Garment enterprises lack of content and substantial sales culture in brand marketing}

China's apparel brand lack of cultural meaning embodied in the brand promotion in the media or was different with culture and corporate culture. In the small garment enterprises, marketing focus only on the results of the process, there is no focus on the process of marketing, there is no meaning to the brand fully demonstrated in the marketing process, which leads to consumer brands and cultural ignorance, not generated brand loyalty. For example, many apparel advertising in film and television that star wearing apparel products using the shooting advertising, consumers are not based solely on corporate identity as reflected in the content of advertising clothing brands, is difficult to distinguish between the products advertised are the clothing company and brand and marketing culture disappeared.

\section{Brand marketing is the key to enhance the core competitiveness of China's garment enterprises}

Apparel development of today, in addition to the functions to meet the needs of cover themselves and stay warm, even more important is the user's inner needs, but also give consumers a wearing apparel experience in this experience to their own identity, personality, taste can be a perfect interpretation, as is consumer demand for an individual. Consumers seek to satisfy their own personal clothing needs, while also bringing in a unique brand experience, corporate culture. Brand culture is reflected by the core competitiveness of enterprises. All enterprise operations are the core competitive edge around the initiative to embark on the brand, from product making the $\mathrm{ad}$ and to store design, every aspect of the matter with brand culture that allowed the image of the brand perception of consumers more clear, enhanced brand strength in the market competition.

The brand marketing strategy in apparel businesses is equipped with the original brand marketing strategy and is no longer suitable for long-term development. Brand marketing strategies should be innovative and modern, fit the psychological needs of consumers, highlighting product features. We should take a wide range of marketing strategies to ensure that corporate brand image in the same time, to enhance the brand's position in market competition.

\section{The brand marketing strategy to enhance marketing for our apparel}

\subsection{Wearing apparel and clothing design and service innovation strategy}

Dress design Innovation and after-sales service strategy is from the perspective of restructuring of corporate brand or brand recycled to adjust product and service strategies for the most unique corporate brand and design products for the market feedback. This design is not simply a product design, but to request the designers to participate marketing to make our products throughout the marketing plan, to highlight enterprise culture and product design. Apparel products should strengthen after-sales service, such as to design according to the consumer demand, so that consumers wear more decent product, this after-sales service will promote personalized garment clothing production. This is different from the individual tailoring of tailored services, which is using modern technology to industrial production and consumer demand for apparel directly linked to the production of services to address the consumer because the fabric, color, tailoring and other reasons to buy not appropriate clothing problem. Through the way of personalized apparel meet consumer needs, enhance the competitiveness of enterprises, expand sales, and get many loyal customers.

\section{2 "Tastes" marketing strategy in garment enterprises}

So called "tastes" marketing strategy is not a concoction of various elements of luxury, but consistent with the brand positioning between the various elements of the set to make the brand more anthropomorphic. Consumers can see for themselves through a variety of sense organs to the presence of the brand. "Tastes" marketing strategy focus on more innovation, brand promotion, brand identity graphics, store design, apparel, clothing, fully reflect the impact of brand, consumers can feel the brand presence at all times. At the same time in the product design 
on the basis of unique corporate culture designed to integrate into the corporate culture among the products, so consumers felt the use of products brought about by the strong taste of the brand. "Taste" in the formulation of marketing strategy is required before an accurate positioning of the brand companies, enterprises should have a long-term planning of development, with distinct features of corporate culture, personality outstanding product design, so as to be more emphasis on "taste" in taste marketing strategy .

\subsection{Clothing company's "lifestyle" marketing tactics}

Clothing Company's "lifestyle" marketing strategy advocated adding life concept inside in the marketing strategy and creating ambassador consumers really impressed with spontaneous brand recognition. With the development of buy clothing goods, the consumers not only take into account the practicality of clothing, more importantly to enable them to feel comfortable and cozy wearing apparel. In the formulation of marketing strategy, the company should be operating elements of the consumer lifestyle, culture consumption habits of consumers in consumer demand has not shown, to adapt them to their lifestyles according to their heart's demand for mining, to creative play, producing the right products, providing appropriate services to create demand and stimulate consumption. Clothing company's "lifestyle" marketing strategy is mainly reflected in the information business to consumer and understanding of the connotation of its own brand clarity require, accurate positioning of the brand .Company can better deal with the interests relationship between organizations, customers and the community and express the consumer's lifestyle demands by products or brand evolved into a particular lifestyle or a status symbol to achieve attract consumers and a stable consumer group.

\section{References}

China National Garment Association. [Online] Available: http://www.cnga.org.cn.

Gary • Armstrong, Philip Kotler. (2007). Marketing. The Chinese People's University Press. 